\title{
PENGGUNAAN WHITE PORTLAND CEMENT DAN PORTLAND COMPOSITE CEMENT TERHADAP KEKUATAN TANAH EKSPANSIF DENGAN UNCONFINED COMPRESSION TEST
}

\author{
Anasthasia Irawati $\mathrm{Ng}^{1}$ dan Aniek Prihatiningsih ${ }^{2}$ \\ ${ }^{1}$ Program Studi Sarjana Teknik Sipil, Universitas Tarumanagara, Jl. Letjen. S. Parman 1, Jakarta \\ Email: anasthasiang@gmail.com \\ ${ }^{2}$ Program Studi Sarjana Teknik Sipil, Universitas Tarumanagara, Jl. Letjen. S. Parman 1, Jakarta \\ Email: aniekp@ft.untar.ac.id
}

\begin{abstract}
ABSTRAK
Pekerjaan konstruksi di bidang Teknik Sipil berkaitan erat dengan struktur bangunan, khususnya aspek yang tak kalah penting yang dianggap sebagai langkah awal dalam memulai pembangunan adalah tanah. Selain sebagai langkah awal dalam pembangunan, tanah juga merupakan bagian terpenting untuk mendukung beban-beban yang akan dipikul di atas tanah tersebut. Pengujian dilakukan untuk mendapatkan hasil dari pengaruh penambahan White Portland Cement dan Portland Composite Cement pada stabilisasi tanah ekspansif daerah Jababeka, Cikarang, serta daya dukung tanah sebagai perbandingan nilai Tes Tekanan Bebas dengan variasi perbandingan 3\%, 6\% dan 9\% dari berat kering tanah dengan waktu pemeraman 3 dan 7 hari. Dapat disimpulkan bahwa nilai unconfined tanah yang dicampurkan dengan semen, baik Portland Composite Cement ataupun White Portland Cement dapat meningkatkan nilai kekuatan tanah ekspansif, serta mempengaruhi daya dukung tanah ekspansif. Dari hasil penelitian diperoleh bahwa nilai kuat tekan bebas tanah mengalami peningkatan seiring dengan bertambahnya kadar persentase semen dan semakin lamanya waktu pemeraman dibandingkan dengan nilai kuat tekan bebas tanah asli. Nilai kuat tekan maksimum pada kadar $9 \%$ Portland Composite Cement sebesar $729.31 \mathrm{kN} / \mathrm{m}^{2}$, sedangkan pada kadar $9 \%$ White Portland Cement sebesar $872.08 \mathrm{kN} / \mathrm{m}^{2}$ dengan waktu pemeraman masing-masing selama 7 hari.
\end{abstract}

Kata kunci: Tanah Ekspansif, White Portland Cement, Portland Composite Cement, Unconfined Compression Test.

\section{PENDAHULUAN}

Pekerjaan konstruksi di bidang Teknik Sipil berkaitan erat dengan struktur bangunan, khususnya aspek yang tak kalah penting yang dianggap sebagai langkah awal dalam memulai pembangunan adalah tanah. Selain sebagai langkah awal dalam pembangunan, tanah juga merupakan bagian terpenting untuk mendukung beban-beban yang akan dipikul di atas tanah tersebut.

Tanah ekspansif merupakan salah satu jenis tanah yang memiliki sifat kembang dan susut yang sangat tinggi, hal ini dapat menyebabkan stabilitas serta kekuatan tanah ekspansif sangat bergantung pada kadar air dalam tanah yang dipengaruhi oleh iklim dan cuaca. Sebagai pendukung konstruksi, tanah ekspansif memerlukan penanganan khusus yang sangat diperlukan guna untuk mendukung pembangunan, salah satunya adalah dengan cara menstabilisasi tanah ekspansif dengan menggunakan bahan kimia, yaitu semen.

Pekerjaan konstruksi juga tidak luput dari metode perbaikan tanah yang semakin berkembang dan diaplikasikan di dalam memulai pembangunan. Metode perbaikan tanah sudah sangat umum diterapkan guna untuk meningkatkan hasil daya dukung pada tanah ekspansif, sehingga tanah tersebut dapat memikul beban-beban yang akan didirikan di atas tanah tersebut.

Tujuan penelitian ini, yaitu untuk mendapatkan hasil dari pengaruh penambahan semen, khususnya untuk membandingkan penggunaan White Portland Cement dengan Portland Composite Cement pada percobaan pencampuran pada sample tanah ekspansif. Dari hasil percobaan ini dapat diketahui dan didapatkan nilai daya dukung tanah sebagai perbandingan nilai kekuatan antara tanah ekspansif yang dicampurkan White Portland Cement dengan tanah ekspansif yang dicampurkan Portland Composite Cement.

Pencampuran White Portland Cement dan Portland Composite Cement ini dilakukan dengan berbagai macam variasi perbandingan, yaitu sebanyak 3\%, 6\% dan 9\% dari berat kering sample tanah dengan waktu pemeraman 3 dan 7 hari. 
Pengujian dilakukan di Laboratorium Mekanika Tanah Universitas Tarumanagara dan didapat hasil pengaruh penambahan antara penggunaan White Portland Cement atau Portland Composite Cement yang dapat dipilih pada stabilisasi tanah ekspansif akhir yang diuji dengan alat Unconfined Compression Test.

Tujuan dari penelitian yang dilakukan ini adalah untuk menganalisis hasil perbandingan antara pencampuran White Portland Cement dan Portland Composite Cement secara terpisah dengan mengunakan uji alat Unconfined Compression Test dan mendapatkan hasil kuat tekan tanah ekspansif yang dicampur dengan White Portland Cement dan Portland Composite Cement dengan rasio perncampuran dan waktu pemeraman yang bervariasi.

Manfaat dari penelitian yang dilakukan adalah untuk memperoleh pengetahuan mengenai pengaruh yang ditimbulkan oleh penambahan variasi rasio pencampuran semen dan lamanya waktu pemeraman terhadap tanah ekspansif dan diharapkan dapat dijadikan sebagai acuan dalam perancangan stabilisasi tanah.

\section{KAJIAN PUSTAKA}

\section{Klasifikasi Karakteristik Tanah}

Kegiatan pembangunan selalu berkaitan erat dengan segala aspek teknik dalam melakukan tahap pembangunan, salah satu yang menjadi dasar penting dalam menopang beban-beban yang akan dipikul diatasnya adalah tanah. Tanah dapat diartikan sebagai bahan yang berasal dari agregat padat berupa butiran-butiran yang tidak tercampur oleh kimia dan partikel padat alami yang tercampur oleh udara dan mineral cair yang berada diantara rongga-rongga tersebut.

Tanah juga berguna sebagai bahan bangunan pada berbagai macam pekerjaan Teknik, khususnya Teknik Sipil, di samping itu tanah berfungsi juga sebagai pendukung pondasi dari bangunan. Selain sebagai pendukung pondasi dari bangunan-bangunan yang akan didirikan diatasnya, para ahli Teknik Sipil harus mengetahui dan mempelajari klasifikasi tanah, baik dari segi sifat-sifat tanah, besaran kekuatan geser, serta nilai kekuatan kapasitas daya dukung yang akan diterimanya.

Ilmu Mekanika Tanah atau Soil Mechanics adalah cabang dari ilmu pengetahuan yang mempelajari sifat fisik dari tanah dan kekuatan massa tanah tersebut bila menerima bermacam-macam gaya dan merupakan penerapan nyata dalam aplikasi prinsip-prinsip mekanika tanah (Braja M. Das, 1991). Geotechnical Engineering merupakan pelaksanaan dari bagian Teknik Sipil yang berhubungan erat dengan material-material alam dan aplikasi dari penerapan-penerapan prinsip dasar mekanika tanah dan batuan.

\section{Karakteristik Tanah Ekspansif}

Tanah ekspansif adalah tanah yang mengalami perubahan volume akibat perubahan kadar air dalam tanah, biasanya tanah ekspansif mengandung mineral-mineral lempung seperti montmorillonite, kaolinite, illite dan smektit yang mampu menyerap air. Ketika mineral tersebut menyerap air, maka volume tanah akan meningkat. Semakin banyak air yang terserap, maka semakin bertambah pula volume tanah. Perubahan volume ini dapat merusak kekuatan struktur bangunan yang menempati tanah tersebut (Laurence D. Wesley, 2010).

Salah satu ciri khas kerusakan yang disebabkan oleh tanah ekspansif, yaitu retaknya pondasi, lantai dan dinding pada suatu bangunan. Kerusakan tersebut dapat terjadi apabila ada gerakan yang signifikan dalam struktur tanah. Pada saat tanah ekspansif mengering, maka akan terjadi penyusutan, di mana penyusutan ini dapat menghilangkan daya dukung bangunan sehingga terjadinya kerusakan struktur bangunan. Celah-celah dalam tanah ini dapat memudahkan penetrasi air, sehingga menghasilkan siklus penyusutan dan pembengkakan (swelling) yang akan menghasilkan tegangan berulang pada struktur tanah.

\section{Uji Penentuan Karakteristik Tanah di Laboratorium}

Dalam suatu pengujian apalagi pengujian laboratorium terdapat beberapa prosedur kerja yang harus diikuti sesuai dengan langkah-langkah kerja yang ada sebelumnya, sehingga pengujian yang dilakukan menghasilkan nilai yang sebenarnya. Pada pengujian ini dilakukan pada sample tanah yang akan digunakan yaitu pengujian karakteristik tanah ekspansif. Adapun pengujian ini terdiri dari:

1. Pengujian kadar air (water content).

2. Pengujian specific gravity.

3. Pengujian batas-batas konsistensi (atterberg limit).

4. Pengujian grain size analysis.

5. Pengujian berat isi.

6. Pengujian pemadatan (compaction).

7. Pengujian $x$-ray diffraction. 


\section{Pengujian unconfined compression test.}

\section{Uji Penentuan Tanah Ekspansif dengan X-Ray Diffraction (XRD)}

Karakterisasi XRD digunakan untuk menentukan jenis serta kandungan dan memberikan informasi-informasi dari struktur mineral suatu bongkahan tanah. Perusahaan yang bergerak dibidang konstuksi, seperti perusahaan semen, menggunakan XRD untuk menjamin nilai mutu suatu bahan yang akan diproduksi secara massal.

Pemrosesan mineral dan pengujian metalurgi adalah proses menentukan kandungan mineral yang terdapat pada sample batuan secara lebih rinci dan khusus. Dengan pengujian mineral processing ini, maka dapat diteliti dengan didapatnya hasil tabel rasio kandungan tanah ekspansif dan grafik Spectographs pada layanan jasa PT. SUCOFINDO SBU Laboratorium Sentral di Jalan Arteri Tol Cibitung No. 1, Cibitung, Bekasi, Jawa Barat.

\section{Stabilisasi Tanah dengan White Portland Cement dan Portland Composite Cement}

Stabilisasi tanah merupakan suatu metode yang diterapkan guna untuk meningkatkan kemampuan daya dukung suatu lapisan tanah. Dengan memberikan treatment khusus terhadap lapisan tanah tersebut (Darwis P. , 2001). Tujuan dari metode stabilisasi tanah, yaitu untuk memperbaiki dan meningkatkan daya dukung tanah, menurunkan permeabilitas tanah, serta menjaga potensi pada lapisan tanah. Stabilisasi tanah dapat dilakukan dengan menggunakan metode stabilisasi kimia, yaitu stabilisasi dengan menggunakan bahan-bahan kimia dan menghasilkan senyawa baru yang bersifat lebih stabil dari pada senyawa yang terdapat dalam massa tanah sebelum stabilisasi dilakukan.

White portland cement atau semen putih adalah semen yang lebih murni dari semen abu dan digunakan untuk pekerjaan penyelesaian (finishing), seperti sebagai filler atau pengisi. Semen jenis ini dibuat dari bahan utama kalsit (calcite) limestone murni. Portland composite cement adalah semen hidrolisis yang dihasilkan dengan cara menghasilkan klinker terutama dari silikat-silikat kalsium yang bersifat hidrolisis (dapat mengeras jika bereaksi dengan air) dengan gips sebagai bahan tambahan. Semen merupakan bahan pengikat yang paling terkenal dan paling banyak digunakan dalam proses konstruksi beton.

\section{Pengujian Unconfined Compression Test}

Pengujian secara unconfined compression strength sangatlah praktis, cepat serta akurat. Pengujian sample bersifat undrained, karena penekanan dilakukan relatif cepat, sehingga tidak ada air yang keluar dari pori sample tanah selama pengujian (Hardiyatmo, 2002). Di sisi lain, pengujian secara unconfined compression strength hanya dapat dipakai untuk menentukan kohesi tanah lempung dalam keadaan jenuh dengan sudut geser dalam sebesar nol, karena percobaan ini tidak cocok digunakan untuk tanah yang berpasir.

Pengujian ini meliputi penentuan tanah kohesi pada kondisi asli. Pada pengujian ini sample yang berbentuk silinder akan diberi beban, sehingga mendapatkan nilai kekuatan maksimum tanah tersebut dalam keadaan kuat tekan bebas sampai mencapai keruntuhan dan juga mengukur regangan tanah tersebut akibat tekanan yang diberikan. Setiap material apabila dikenai beban, maka akan mengalami perubahan deformasi atau bentuk. Gaya atau tekanan per satuan luas disebut sebagai stress atau $\sigma$. Selain stress, perubahan bentuk dalam hal ini dibuktikan dengan perubahan dalam satuan panjang atau $\Delta \mathrm{L}$ yang dibanding dengan panjang semula, disebut sebagai strain atau $\varepsilon$.

Unconfined compression strength atau pengujian kuat tekan bebas tanah untuk menentukan nilai kekuatan dengan sample berbentuk silinder hasil dari pemadatan. Pengujian ini menggunakan mesin tekan untuk menekan sample yang dibentuk silinder dari satu arah (uniaksial). Perbandingan antara tinggi dan diameter sample mempengaruhi nilai kuat tekan sample uji (Gogot S. B., 2011). Untuk pengujian kuat tekan secara umum digunakan perbandingan $\mathrm{L}=2 \mathrm{D}$. L adalah length atau panjang dari sample sedangkan D adalah diameter dari sample tanah yang akan diuji. Sebagai standard pengujian berpedoman pada standar ASTM D 2166 mengenai Unconfined Compressive Strength.

\section{METODOLOGI PENELITIAN}

Dalam penelitian lokasi pengambilan sample tanah dari daerah Jababeka, Cikarang. Penelitian ini dilakukan pada sample tanah ekspansif (tanah asli) dan pada tanah ekspansif yang diberikan tambahan stabilisasi kimiawi berupa penambahan semen White Portland Composite Cement dan Portland Composite Cement dengan berbagai variasi rasio pencampuran dan waktu pemeraman.

Untuk mendapatkan hasil penelitian yang lebih akurat, maka diperlukan penelitian laboratorium yang berguna untuk mendapatkan data tentang jenis dan sifat tanah, baik dalam keadaan tanah asli ataupun akibat diberi pembebanan pada sample tanah. Jenis percobaan yang diterapkan pada laboratorium dapat dibagi menjadi dua bagian, yaitu:

A. Sifat fisik tanah (Index Properties), dimana sifat tanah dalam keadaan asli yang dapat digunakan untuk menentukan jenis tanah. 
B. Sifat mekanis tanah (Engineering Properties), dimana sifat tanah dengan diberi pembebanan dan dapat digunakan untuk menentukan parameter tanah.

\section{HASIL DAN PEMBAHASAN}

Pengujian karakteristik tanah dilakukan untuk dapat menentukan dan menyimpulkan jenis dan sifat fisik tanah sample yang akan digunakan oleh peneliti di Laboratorium Mekanika Tanah Program Studi Teknik Sipil Fakultas Teknik Universitas Tarumanagara.

Setelah didapat hasil tanah sample, yaitu berupa tanah ekspansif, maka peneliti dalam melanjutkan uji sample dengan melakukan Unconfined Compression Test. Berikut hasil uji karakteristik tanah.

Tabel 1. Hasil Uji Kadar Air (Water Content)

\begin{tabular}{|c|c|}
\hline Sample & Water Content (\%) \\
\hline $\mathrm{A}$ & 42 \\
\hline $\mathrm{B}$ & 42 \\
\hline $\mathrm{C}$ & 42 \\
\hline Rata-rata & 42 \\
\hline
\end{tabular}

Tabel 2. Hasil Uji Specific Gravity

\begin{tabular}{|c|c|}
\hline Sample & GS \\
\hline $\mathrm{A}$ & 2.78 \\
\hline $\mathrm{B}$ & 2.80 \\
\hline Rata-rata & 2.79 \\
\hline
\end{tabular}

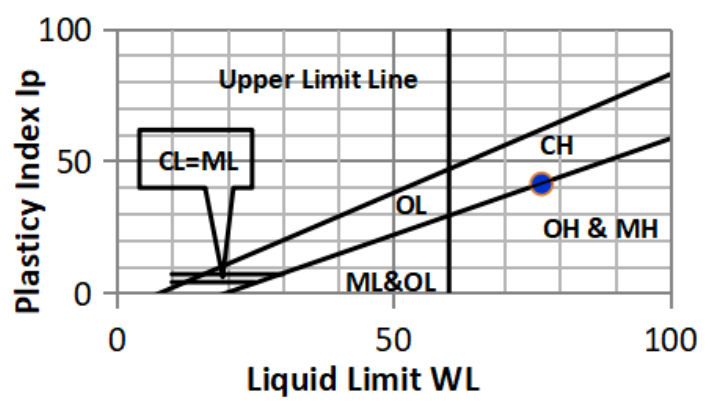

Gambar 1. Grafik Uji Atternerg Limit

Tabel 3. Hasil Uji Atterberg Limit

\begin{tabular}{|c|c|}
\hline Batas Konsistensi & Persentase (\%) \\
\hline Liquid Limit (LL) & 76.73 \\
\hline Plastic Limit (PL) & 35.50 \\
\hline Plasticity Index (PI) & 41.23 \\
\hline
\end{tabular}




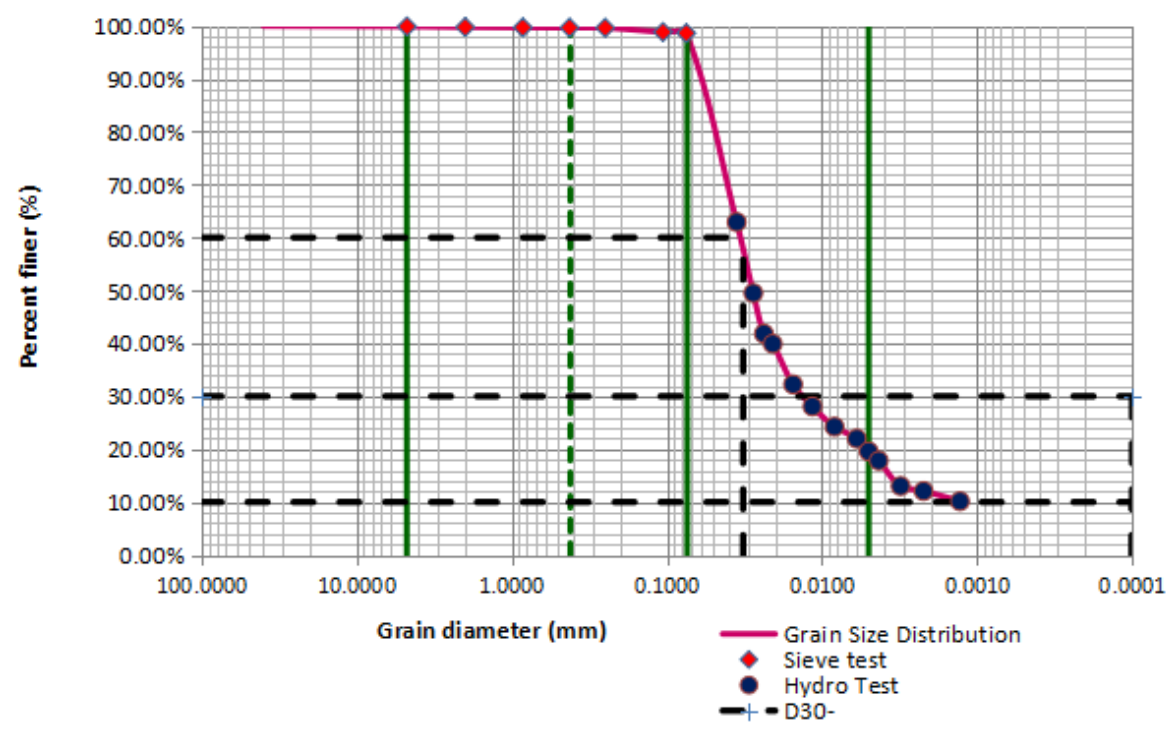

Gambar 2. Grafik Uji Grain Size Analysis Sample A

Tabel 4. Hasil Uji Grain Size Analysis Sample A

\begin{tabular}{|c|c|}
\hline Jenis Butiran & Persentase (\%) \\
\hline Kerikil & 0 \\
\hline Pasir & 1.36 \\
\hline Lempung & 19.58 \\
\hline Lanau & 79.06 \\
\hline
\end{tabular}

GRAIN SIZE DISTRIBUTION CIKARANG - JABABEKA

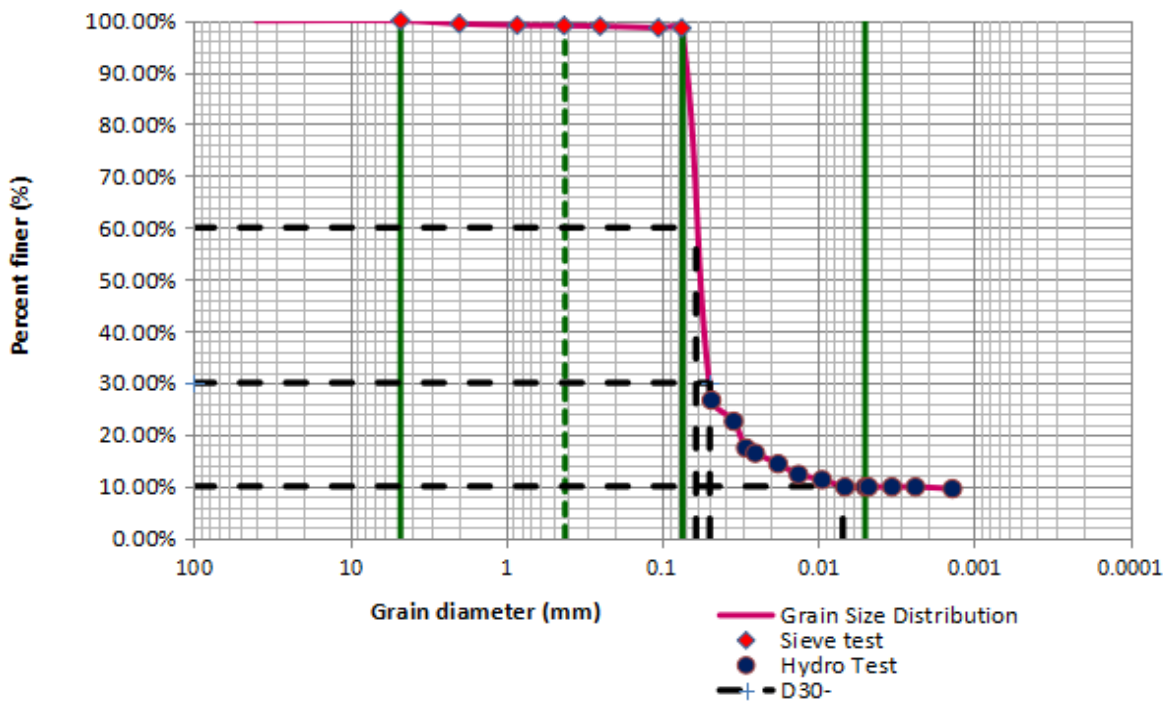

Gambar 3. Grafik Uji Grain Size Analysis Sample B 
Tabel 5. Hasil Uji Grain Size Analysis Sample B

\begin{tabular}{|c|c|}
\hline Jenis Butiran & Persentase (\%) \\
\hline Kerikil & 0 \\
\hline Pasir & 1.36 \\
\hline Lempung & 19.41 \\
\hline Lanau & 79.23 \\
\hline
\end{tabular}

Dengan membandingkan besaran nilai indeks plastisitas dan rata-rata persentase lempung pada uji grain size analysis, didapat bahwa $\mathrm{A}=4.34$, di mana $\mathrm{A}>1.25$. Dapat disimpulkan bahwa aktivitas tanah ekspansif di daerah Jababeka dikategorikan sebagai aktivitas aktif.

Tabel 6. Hasil Uji Berat Isi

\begin{tabular}{|c|c|c|c|c|}
\hline Can & \multicolumn{2}{|c|}{ MT 8} & \multicolumn{2}{|c|}{ MT 18} \\
\hline Berat Can + Ring & \multicolumn{2}{|c|}{103.5 gram } & \multicolumn{2}{|c|}{102.4 gram } \\
\hline \multirow{3}{*}{ Tinggi } & 4.05 & \multirow{3}{*}{$4.05 \mathrm{~cm}$} & 4.07 & \multirow{3}{*}{$4.05 \mathrm{~cm}$} \\
\hline & 4.05 & & 4.04 & \\
\hline & 4.05 & & 4.05 & \\
\hline \multirow{3}{*}{ Diameter } & 4.12 & \multirow{3}{*}{$4.11 \mathrm{~cm}$} & 4.13 & \multirow{3}{*}{$4.13 \mathrm{~cm}$} \\
\hline & 4.12 & & 4.12 & \\
\hline & 4.1 & & 4.13 & \\
\hline Berat Tanah Basah + Can + Ring & \multicolumn{2}{|c|}{200.8 gram } & \multicolumn{2}{|c|}{197.5 gram } \\
\hline Berat Tanah Kering + Can + Ring & \multicolumn{2}{|c|}{173.2 gram } & \multicolumn{2}{|c|}{168 gram } \\
\hline Berat Volume & \multicolumn{2}{|c|}{$1.83 \mathrm{gr} / \mathrm{cm}^{3}$} & \multicolumn{2}{|c|}{$1.77 \mathrm{gr} / \mathrm{cm}^{3}$} \\
\hline Berat Isi & \multicolumn{4}{|c|}{$1.80 \mathrm{gr} / \mathrm{cm}^{3}, 17.67 \mathrm{kN} / \mathrm{m}^{3}$} \\
\hline
\end{tabular}

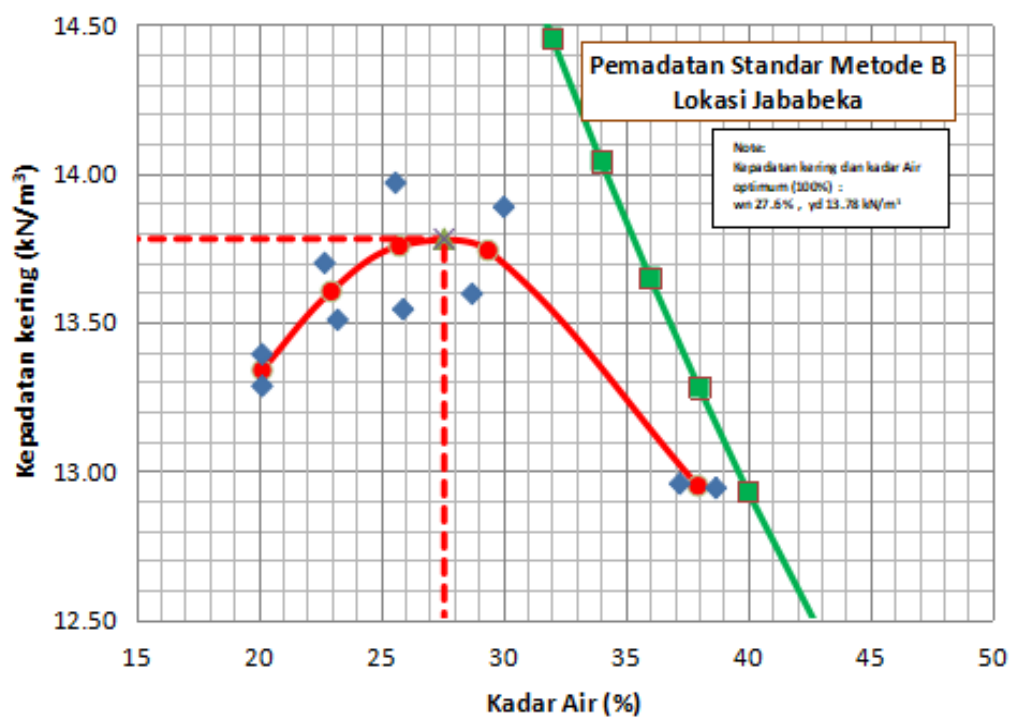

Gambar 4. Grafik Uji Compaction 
Jurnal Mitra Teknik Sipil

Vol. 1, No. 1, Agustus 2018 hlm: 39-47

Tabel 7. Hasil Uji Compaction

\begin{tabular}{|c|c|}
\hline Kadar Air Optimum (\%) & Berat Isi $\left(\mathrm{kN} / \mathrm{m}^{3}\right)$ \\
\hline 27.6 & 13.78 \\
\hline
\end{tabular}

Tabel 8. Hasil Uji X-Ray Diffraction (XRD)

\begin{tabular}{|c|c|c|}
\hline Sample Mark & Mineral/s or Phase/s Identified & $\begin{array}{c}\text { Estimation by Normalized } \\
\text { RIR Bulk XRD } \\
(\%)\end{array}$ \\
\hline \multirow{6}{*}{$\begin{array}{c}\text { Sample } 1 \\
\text { JABABEKA }\end{array}$} & Quartz $\mathrm{SiO}_{2}$ & 80 \\
\hline & $\begin{array}{c}\text { Montmorillonite } \\
(\mathrm{Ca}, \mathrm{Na})_{0.32} \mathrm{Al}_{2}\left(\mathrm{Si}_{2} \cdot \mathrm{Al}_{4} \mathrm{O}_{10}(\mathrm{OH}) x \mathrm{H}_{2} \mathrm{O}\right.\end{array}$ & 11 \\
\hline & Kaolinite $\mathrm{Al}_{2}\left(\mathrm{Si}_{2} \mathrm{O}_{5}\right)(\mathrm{OH})_{4}$ & 9 \\
\hline & Calcite $\mathrm{CaCO}_{3}$ & Trace \\
\hline & Albite $\mathrm{Na}_{0.685} \mathrm{Ca}_{0.347} \mathrm{Al}_{1.46} \mathrm{Si}_{2.54} \mathrm{O}_{8}$ & Trace \\
\hline & $\mathbf{X X X}$ & $100 \%$ \\
\hline
\end{tabular}

Dari hasil penelitian-penelitian yang telah dilakukan oleh penulis, telah didapat hasil korelasi antara uji unconfined compression test pada sample portland composite cement dan sample white portland cement yang menggunakan compacted sample dengan membandingkan besar nilai kuat tekan bebas atau tegangan runtuh $\left(\mathrm{q}_{\mathrm{u}}\right)$ rata-rata pada kondisi rasio kadar pencampuran semen dibandingkan terhadap waktu pemeraman sample.

Tabel 9. Hasil Uji Unconfined Compression Test pada Rasio Kadar Pencampuran Semen dengan Waktu Pemeraman

\begin{tabular}{|c|c|c|c|c|c|c|}
\hline $\begin{array}{c}\text { Waktu Peram } \\
(\text { Hari })\end{array}$ & $\begin{array}{c}\mathrm{q}_{\mathrm{u}} \text { Portland } \\
\text { Composite } \\
\text { Cement 3\% } \\
\left(\mathrm{kN} / \mathrm{m}^{2}\right)\end{array}$ & $\begin{array}{c}\mathrm{q}_{\mathrm{u}} \text { Portland } \\
\text { Composite } \\
\text { Cement 6\% } \\
\left(\mathrm{kN} / \mathrm{m}^{2}\right)\end{array}$ & $\begin{array}{c}\mathrm{q}_{\mathrm{u}} \text { Portland } \\
\text { Composite } \\
\text { Cement } 9 \% \\
\left(\mathrm{kN} / \mathrm{m}^{2}\right)\end{array}$ & $\begin{array}{c}\mathrm{q}_{\mathrm{u}} \text { White } \\
\text { Portland } \\
\text { Cement 3\% } \\
\left(\mathrm{kN} / \mathrm{m}^{2}\right)\end{array}$ & $\begin{array}{c}\mathrm{q}_{\mathrm{u}} \text { White } \\
\text { Portland } \\
\text { Cement 6\% } \\
\left(\mathrm{kN} / \mathrm{m}^{2}\right)\end{array}$ & $\begin{array}{c}\mathrm{q}_{\mathrm{u}} \text { White } \\
\text { Portland } \\
\text { Cement } 9 \% \\
\left(\mathrm{kN} / \mathrm{m}^{2}\right)\end{array}$ \\
\hline 3 & 215.93 & 321.66 & 551.26 & 345.82 & 544.13 & 635.19 \\
\hline 7 & 315.59 & 685.40 & 729.31 & 587.10 & 748.59 & 872.08 \\
\hline
\end{tabular}




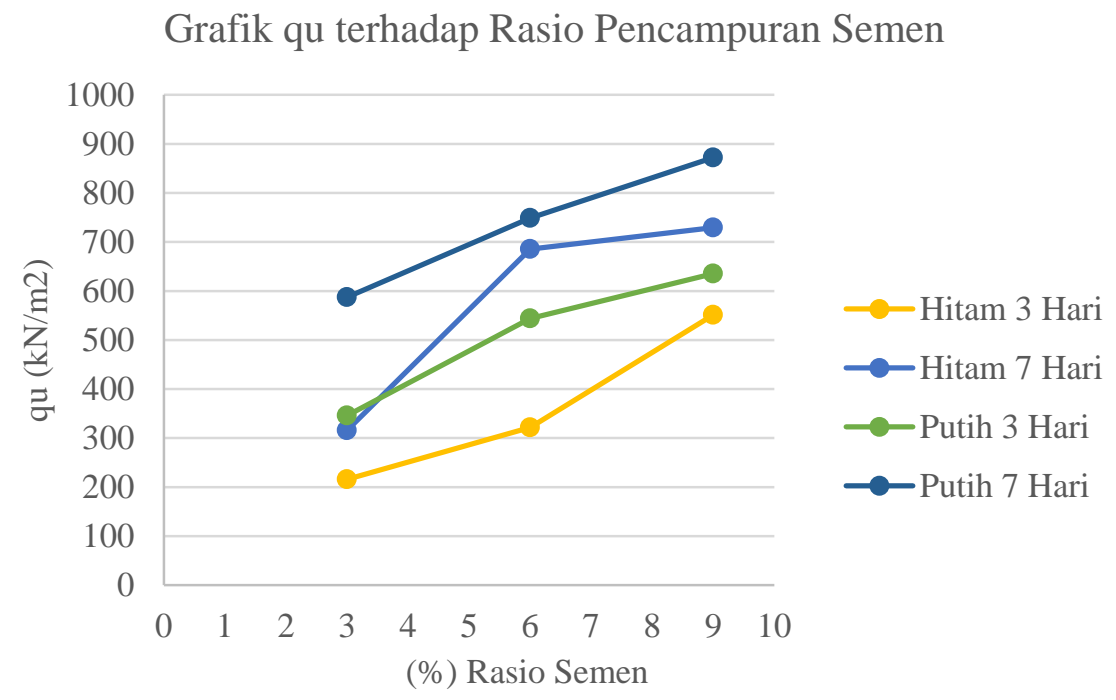

Gambar 5. Korelasi Tegangan Runtuh $\left(\mathrm{q}_{\mathrm{u}}\right)$ Rata-Rata dan Rasio Kadar Pencampuran Semen

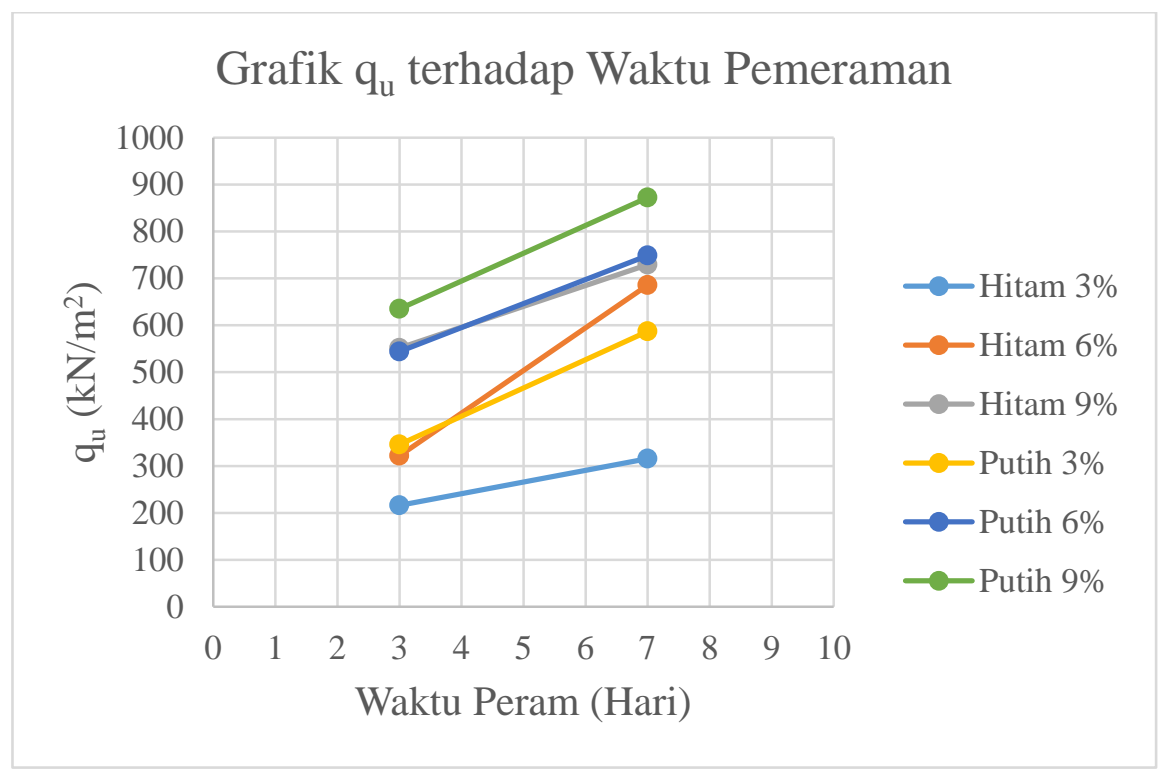

Gambar 6. Korelasi Tegangan Runtuh $\left(\mathrm{q}_{\mathrm{u}}\right)$ Rata-Rata dan Waktu Pemeraman

Nilai tegangan runtuh $\left(\mathrm{q}_{\mathrm{u}}\right)$ tertinggi diperoleh pada kondisi sample white portland cement pada rasio kadar pencampuran sebanyak $9 \%$ dengan waktu pemeraman selama 7 hari, yaitu sebesar $872.08 \mathrm{kN} / \mathrm{m}^{2}$.

\section{KESIMPULAN}

Dari hasil percobaan-percobaan laboratorium yang telah diteliti, dapat ditarik kesimpulan-kesimpulan yang dirangkum sebagai berikut.

1. Berdasarkan hasil analisis dari percobaan di laboratorium Universitas Tarumanagara dan PT. SUCOFINDO SBU Laboratorium Sentral, tanah di daerah Cikarang, khususnya di Jababeka, didapat nilai IP tanah tersebut adalah $41.22 \%$ dan memiliki kandungan montmorillonite sebesar 11\%. Dapat disimpulkan bahwa tanah tersebut terbukti merupakan tanah ekspansif dengan nilai aktivitas sebesar 4.34 dan dikategorikan sebagai tanah yang aktif. 
2. Dari hasil pengujian dengan penambahan $9 \%$ dan waktu pemeraman 7 hari didapatkan nilai kuat tekan bebas atau tegangan runtuh $\left(\mathrm{q}_{\mathrm{u}}\right)$ pada kondisi sample White Portland Cement, yaitu sebesar $872.08 \mathrm{kN} / \mathrm{m}^{2} \mathrm{dan}$ pada kondisi sample Portland Composite Cement, yaitu sebesar $729.30 \mathrm{kN} / \mathrm{m}^{2}$. Hasil tegangan maksimum didapat dengan penambahan White Portland Cement.

3. Penambahan semen, khususnya White Portland Cement, dapat dipergunakan sebagai bahan tambahan untuk stabilisasi tanah ekspansif, hal ini terbukti dengan tegangan runtuh $\left(\mathrm{q}_{\mathrm{u}}\right)$ pada kondisi sample White Portland Cement lebih baik dan lebih tinggi daripada tegangan runtuh $\left(\mathrm{q}_{\mathrm{u}}\right)$ pada kondisi sample Portland Composite Cement.

4. Dari hasil pengujian Unconfined Compression Test pada sample alami dan sample semen, nilai regangan pada sample semen lebih kecil dibandingkan nilai regangan pada sample alami. Penambahan semen dapat mengurangi besaran nilai regangan seiring dengan bertambahnya kadar pencampuran semen.

\section{DAFTAR PUSTAKA}

Ali, M. dan Satibi, S. (2015). Pengaruh Penambahan Semen terhadap Kuat Geser Lempung Sebelum dan Sesudah Penjenuhan. Jom FTeknik Volume 2 Nomor 1. Universitas Riau.

ASTM Standard D 2166-00. 2000. Standart Test Method for Unconfined Compressive Strength for Cohesive Soil. ASTM International, West Conshohocken, PA.

Budi, G. S. (2011). Pengujian Tanah di Laboratorium (Penjelasan dan Panduan). Jilid I. Penerbit Graha Ilmu. Yogyakarta.

Bowles, Joseph E. (1993). Sifat-sifat Fisis Tanah dan Geoteknis Tanah (Mekanika Tanah). Penerbit Erlangga. Jakarta.

Das, Braja M. (1991). Mekanika Tanah (Prinsip-prinsip Rekayasa Geoteknis) Jilid I. Penerbit Erlangga. Jakarta.

Das, Braja M. dan Sobhan, K. (2012). Principles of Geotechnical Engineering $8^{\text {th }}$ edition, SI. Amerika.

Forssblad, L. (1989). Kompaksi (Pemampatan) Urukan Tanah dan Batuan dengan Getaran. Bina Aksara. Jakarta.

Hardiyatmo, H. C. (2002). Mekanika Tanah I. Penerbit Gadjah Mada University Press. Yogyakarta.

Lesmana, R.I., Muhardi dan Nugroho, S. A. (2016). Stabilitas Tanah Plastisitas Tinggi dengan Semen. Jom FTeknik Volume 3 Nomor 2. Universitas Riau.

Panguriseng, D. (2001). Stabilisasi Tanah. Buku Ajar. Universitas “45” Makassar.

Panguriseng, D. (2017). Dasar-Dasar Teknik Perbaikan Tanah. Penerbit Pustaka AQ. Yogyakarta.

Pirmadona, S., Muhardi dan Kurniawandy, A. (2015). Stabilitas Tanah Plastisitas Rendah dengan Semen. Jom FTeknik Volume 2 Nomor 2. Universitas Riau.

Raharmadi, B. (2017). Meningkatkan Nilai Kuat Tekan Bebas (UCS) Tanah Manyawang Distabilisasi dengan Semen. Jurnal Infrastruktur Volume 3 Nomor 1. Teknik Jalan dan Jembatan Ahli Muda. Direktorat Jenderal Bina Marga. Kementrian Pekerjaan Umum dan Perumahan Rakyat.

Ranggan, P. R., Masiku, H., Paemboman, M. L., Padang, I. dan Upa, Y. (2017). Studi Peningkatan Daya Dukung Tanah Lempung dengan Menggunakan Semen. Konferensi Nasional Teknik Sipil 11 Volume 1 Geoteknik. Universitas Tarumanagara.

Shirley, L. H. (1987). Penuntun Praktis Geoteknik dan Mekanika Tanah (Penyelidikan Lapangan dan Laboratorium). Penerbit Nova. Jakarta.

Skempton, A. W. (1953). The Colloidal Activity of Clays. Proceedings $3^{\text {rd }}$ International Conference on Soil Mechanics and Foundation Engineering. Volume 1 Number 57 - 61. London.

Smith, M. J. (1992). Mekanika Tanah (Soil Mechanics). Penerbit Erlangga. Jakarta.

Sosrodarsono, S. dan Nakazawa, K. (2000). Mekanika Tanah dan Teknik Pondasi. PT. Pradnya Paramita. Jakarta.

Wesley, L. D. (2010). Mekanika Tanah untuk Tanah Endapan dan Residu. Penerbit ANDI. Yogyakarta. 